\title{
The Monitoring System of Sulfur Dioxide Gas Using a Web-based Wireless Sensor
}

\author{
Sunarno $^{1}$, Purwanto ${ }^{2}$, Suryono ${ }^{3}$ \\ \{narnofisika91@gmail.com ${ }^{1}$ \} \\ Universitas Diponegoro, Indonesia ${ }^{1,2,3}$ \\ Universitas Negeri Semarang, Indonesia ${ }^{1}$
}

\begin{abstract}
Air pollution is a problem that has a serious impact on environmental damage and health. Therefore, it is very important to have a good air pollution monitoring system to obtain data that can describe current air quality conditions. This study employs the design of a continuous, online and real-time air quality monitoring system using the IoT platform and web. The system is made using the Arduino Uno development board based on Mega2560, several sensors including anemometer module, MQ-136, SHT15, and sim900 GSM module which functions as a communication medium between that device and the webserver. The software uses C-language for Arduino as its embedded system and PHP-MySQL for building web applications. The function of the web server in this system is to inform the air quality to the public through the internet as effectively as possible. This system has great potential to strengthen the existing ISPU station. The results of this research show that the device can measure $\mathrm{SO}_{2}$ concentration of exhaust gases from diesel cars and send data to a web server using the internet network.
\end{abstract}

Keywords: Air Pollution, IoT, Wireless Network, Web.

\section{Introduction}

Motor vehicle emissions contribute approximatley $70 \%$ of air pollution in Indonesia, while the others are contributed by industrial and domestic pollution. Air pollution can have a serious impact on environmental damage and human health problems. The Environment Protection Agency (EPA) has identified 6 (six) air pollutants including carbon monoxide $(\mathrm{CO})$, nitrogen dioxide $\left(\mathrm{NO}_{2}\right)$, ozone $\left(\mathrm{O}_{3}\right)$, particulate matter $(\mathrm{PM})$, sulfur dioxide $\left(\mathrm{SO}_{2}\right)$, and Plumbum $(\mathrm{Pb})$ [1]. The air pollutants such as $\mathrm{SO}_{2}, \mathrm{NOX}$, and PM can cause respiratory tract irritation, asthma, pneumonia, bronchitis, while $\mathrm{CO}$ and $\mathrm{SO}_{2}$ gases can cause acid rain and the greenhouse effect [2][3][4].

Based on the level of air pollution and its impact, then air quality monitoring becomes very important to do. Air quality is usually expressed in a number/index. In Indonesia, the air quality index which is used officially is Indeks Standar Pencemaran Udara (ISPU) or the Air Pollution Standards Index, by the Decree of the State Minister of Environment Number KEP45/MENLH/1997 [5]. ISPU data are obtained from the operating of ambient air pollution monitoring stations automatically. The operation of air pollution monitoring systems can produce some data, both concentration data, weather condition data, and the others, where the data is used to analyze health symptoms and environmental damage. At present, there are many air quality monitoring stations that are not functioning properly, because many pieces of 
equipment are damaged. The repairing effort was not easy to do because the existing equipment was made in another country, whereas to do the replacement, it had to pay a significant amount.

At present, air quality monitoring system technology is available that is relatively inexpensive, self-made, and it has small dimensions, which can connect sensors, actuators, controlling devices with other objects using the internet network. The technology is related to a concept called the Internet of Things (IoT) [6]. Some research uses the IoT concept, such as research on the development of carbon monoxide detection systems using IoT [7], indoor air quality monitoring and notification systems with the IoT platform [8], and air pollution mapping using motion sensors based on the internet of things [9]. The IoT concept has been widely applied to various fields such as industry, agriculture, transportation, health, security, and the environment. The advantages of this concept, namely the low cost, the small dimension, the low power, the ease to operate, the wider time coverage and area, and the data that can be available on websites, smartphones, and the others [10]. The use of an IoT-based sensor network is very effective and efficient in detecting and sending air pollutant data quickly [11]. Therefore the use of the IoT platform and wireless sensor network is very important because the public will obtain air quality information needed online and in realtime.

\section{Research Method}

This research is experimental study, which consist of two steps, namely development and implementation of system. The system development phase start from purchasing components, making electronic circuit schemes, and device manufacturing. After manufacturing the device is complete, then the next step is to calibrate and test the system.

\subsection{Design of air pollution monitoring system}

Figure 1 shows a design of the air quality monitoring system. The system consists of several components, such as sensor systems, internet connections, databases, and computers. The sensor system consists of $\mathrm{SO}_{2}$ sensor (MQ-136), temperature and humidity sensor (SHT15), wind speed sensor, microcontroller, and GSM module. The function of the sensor is to read the physical quantities that occur in an area and convert to analog signal (voltage), the analog signal is processed by the microcontroller into the measurement data, and then the data are sent to the server using the internet network. Data stored in the database are $\mathrm{SO}_{2}$ data $(\mathrm{ppm})$, temperature data $\left({ }^{\mathrm{O}} \mathrm{C}\right)$, relative humidity $(\%)$, and air velocity $(\mathrm{km} / \mathrm{hour})$. The measurement results are displayed in two forms, including graphs and tables. The data can be accessed via the web.

Figure 2 shows the schematic diagram and actual instrument of air pollution system. This diagram can explain clearly, what components are needed, signal propagation, and how the process works. The three-box system is an actual manifestation of air pollution monitoring equipment. 


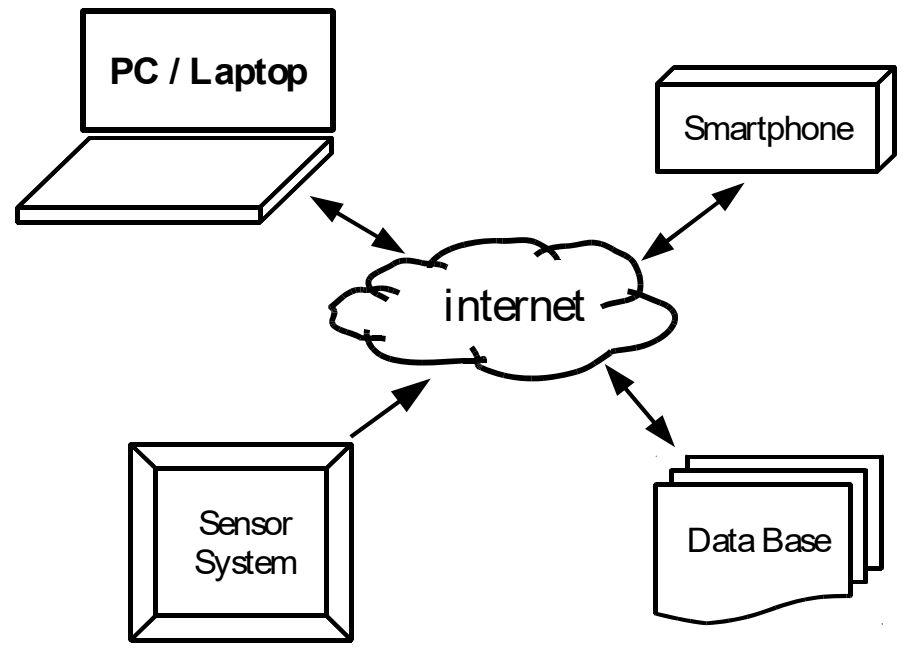

Fig. 1. Design of the air pollution monitoring system.

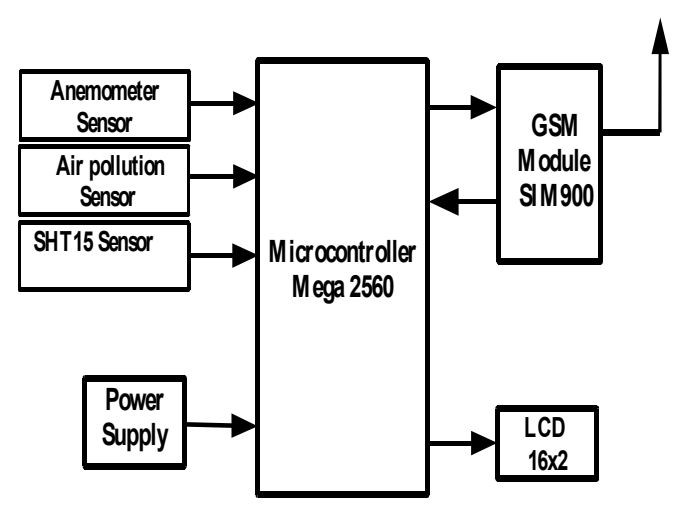

(a)

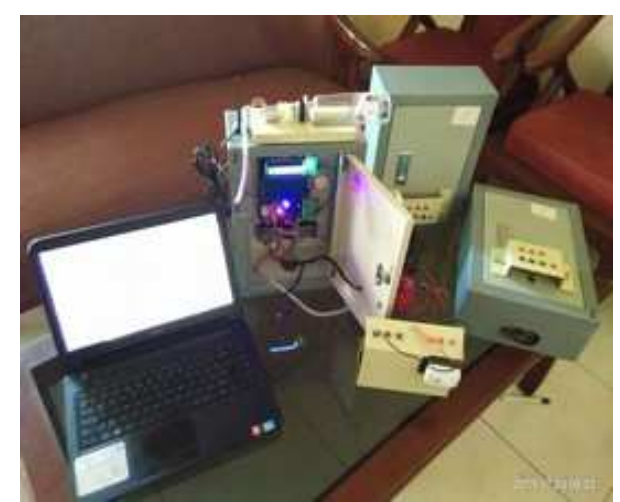

(b)

Fig. 2. (a). The Schematic diagram and (b). actual instrument of air pollution system.

\subsection{Calibration of the System}

The system which has been made must be calibrated. The calibration of the $\mathrm{SO}_{2}$ sensor has carried out at BBTPPI (The center of industrial pollution control technology), Semarang City, and Central Java. The material of a test sample is the exhaust gas from generators of diesel-fueled. The exhaust gas has been put into an acrylic box with dimensions of $40 \mathrm{~cm} \times 30$ $\mathrm{cm} \times 30 \mathrm{~cm}$ and with 1 inlet-outlet. The results obtained are $\mathrm{SO}_{2}$ concentration data from standard equipment (Portable Combustion Gas Analyzer) and ADC data from the tested 
instrument. Then the data are plotted in the graph. The obtained line equation is used as a correction for the test instrument.

\subsection{Experimental Session}

The series of measurement schemes can be shown in Figure 4
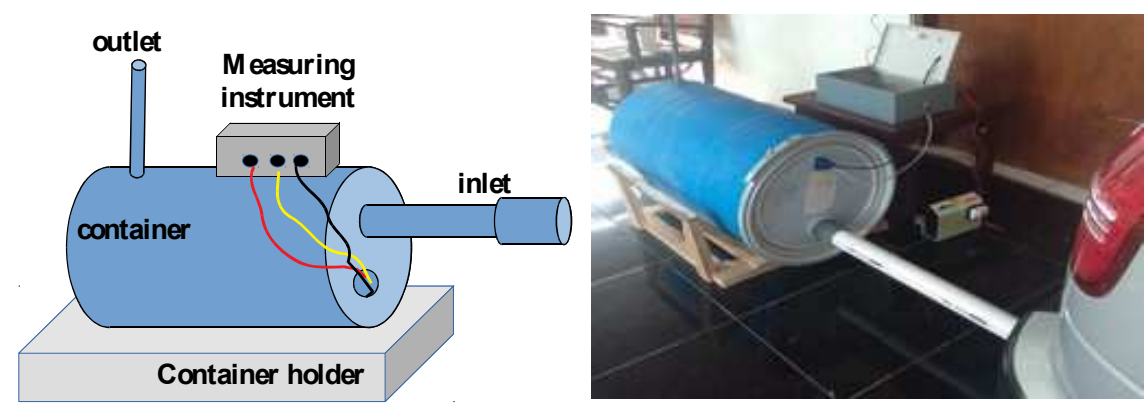

Fig. 4. Schematic diagram and the actual form of the exhaust emissions container

At this experimental stage, the measurements of $\mathrm{SO}_{2}$ concentration from exhaust gases of diesel-fueled vehicles are carried out in the UNNES workshop. The exhaust gas is placed in a container to maintain its homogeneity. Before the $\mathrm{SO}_{2}$ sensor used, it must be heated first for about 3-10 minutes to keep it stable. Measurement was made for 60 minutes. The first 15 minutes, the measurement is done when the exhaust gas put into a container. Then the engine is turned off, and all the inlet and outlet of a container closed. The measurement is continued for ten minutes. After that, all container inlets and outlets are opened, and the measurement continued for 35 minutes.

\section{Result and Discussion}

\subsection{The Result of Calibration System}

The calibration is a comparison between the measurement value of a standard device with the measurement value of the instrument being tested. The calibration process was carried out at BBTPPI and it obtained two data, both SO2 concentration data and ADC (Analog to Digital Converter) data from the tested device. The data plotted in the graph can be seen in Figure 5. The straight-line equation is used to improve the SO2 sensor output. The corrections are made by adding the equation to the source code. 


\section{Graph of SO2 sensor calibration}

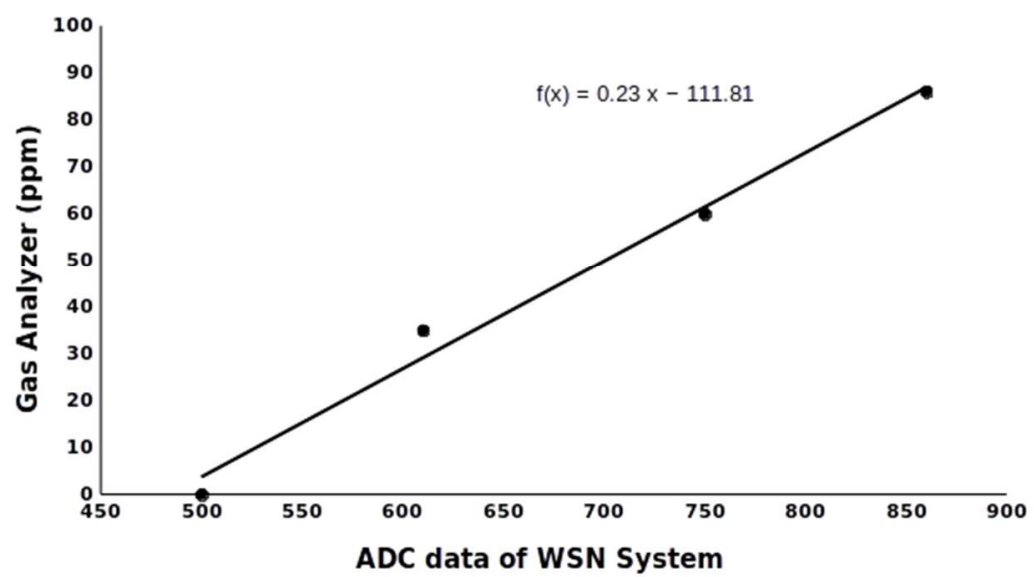

Fig. 5. Graph of sulfur dioxide calibration.

Based on Figure 5, we get a straight-line equation, $y=0.25 x+111.81$, where $x$ represents the value of $\mathrm{ADC}$ while $y$ represents the concentration of $\mathrm{SO}_{2}$. The straight-line equation is used as a corrector to the output of the device, by inserting it into a program. Program code that has been written then injected into the Arduino system. Then, the system is retested to find out whether there is still a difference between the two measurements. The use of the calibration method is very appropriate to produce accurate measurement results [12]. Actually, the goal of calibration is to minimize any measurement uncertainty by ensuring the accuracy of test equipment. Calibration quantifies and controls errors or uncertainties within measurement processes to an acceptable level. The program part that describes the calibration process, is shown as follows

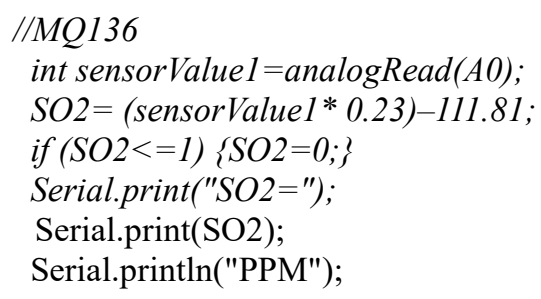

3.2 The Concentration of SO2, Temperature, and Humidity from Diesel Vehicle Exhaust Gases in a Container and its Relationship

The exhaust gases which are discharged from the engine contain several constituents that are harmful to human health and to the environment, one of them is sulfur dioxide $\left(\mathrm{SO}_{2}\right)$. The $\mathrm{SO}_{2}$ gas is generated from the sulfur present in diesel fuel. The concentration of $\mathrm{SO}_{2}$ in the exhaust gas depends on the sulfur content of the fuel.

In this research, sample used is the exhaust gas of diesel-fueled vehicles. The researcher used one brand of car, with a different year of manufacture. There are three samples, namely $\mathrm{X} 1$ which is representing car X with the manufacture year 2019, X2 representing a car, its 
name is $\mathrm{X}$ and the manufacture year is 2017 and $\mathrm{X} 3$ representing car $\mathrm{X}$ with the manufacture year 2009. The graph of three parameters can be shown in figure 6 .

\section{Graph of SO2, Temperature and Relative Humidity data}

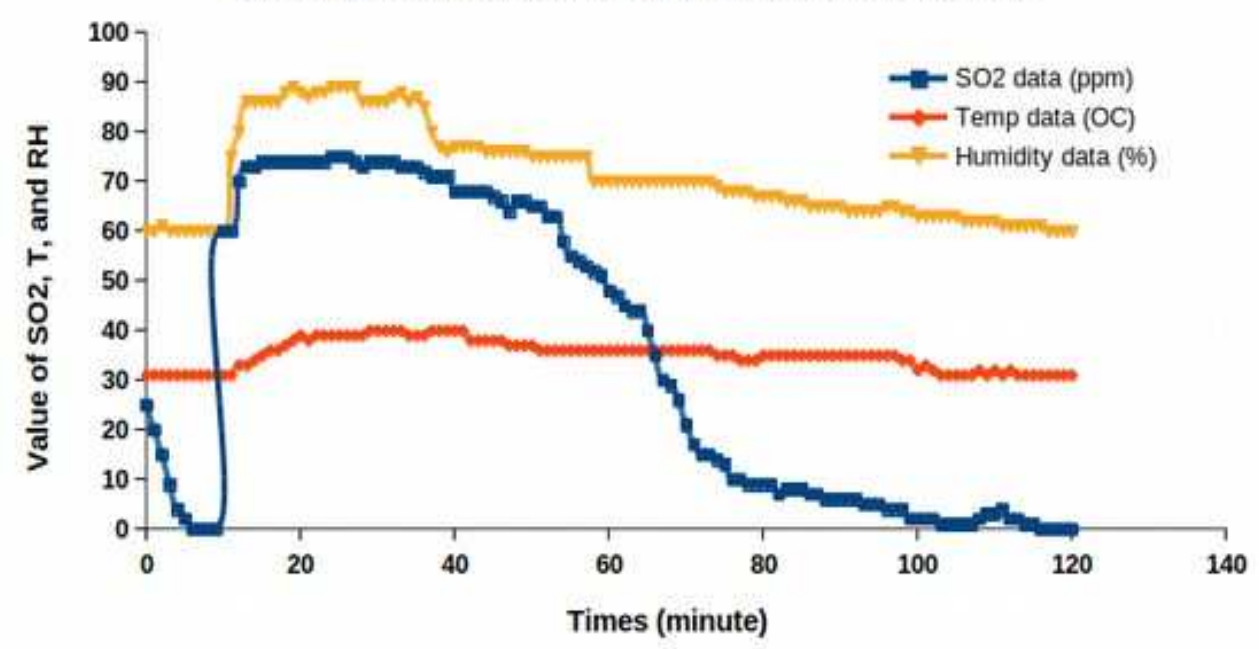

Fig. 6. Graph of sulfur dioxide, temperature and relative humidity of $\mathrm{X}_{1}$ vehicle exhaust gas in a container.

Based on Figure 6, it can be seen that in minutes $0-5$, the concentration of $\mathrm{SO}_{2}$ has decreased to $0 \mathrm{ppm}$, this shows that there is a heating process of the sensor to be ready for use, while the temperature and humidity are relatively stable in the range of $31^{\circ} \mathrm{C}$ and $60 \%$. This process is used to determine the initial conditions before being given a treatment. After the process, in the $10^{\text {th }}$ minute, the engine of the $\mathrm{X} 1$ car was started, so that the exhaust gas entered the container. The concentration of $\mathrm{SO}_{2}$ increased from $0 \mathrm{ppm}$ to $60 \mathrm{ppm}$ until it is stable in the range of $75 \mathrm{ppm}$ for 15 minutes. Relative air humidity increased by $26 \%$, while temperatures increased by $6^{\circ} \mathrm{C}$. The temperature rise is caused by the entry of relatively hot exhaust gas in a container, while the air humidity rise is caused by water vapor contained in the exhaust gas. In the $25^{\text {th }}$ minute, then the engine is turned off, and all input and output pipes of the container are closed and the measurement is taken again for ten minutes. The results showed that $\mathrm{SO}_{2}$ concentration was around $74 \mathrm{ppm}$ while the temperature and humidity were relatively stable in the range of $37^{\circ} \mathrm{C}$ and $86 \%$. Then, in the $36^{\text {th }}$ minute until the end, all the channels in the container are opened. The concentration of $\mathrm{SO}_{2}$, temperature, and humidity has decreased to the initial condition. This is caused by the discharge of all exhaust gases in the container. Based on the graph in Figure 6, it appears that from 50 to 120 minutes, $\mathrm{SO}_{2}$ concentrations decreased non-linearly. The decrease of a gas concentration non-linearly with time also occurred in $\mathrm{CO}$ gas [13]. The measurement and analysis of data from the three samples can be seen in Table 1. This data was taken about 15 minutes, after two minutes the engine is turned on. 
Table 1. Measurement and Analysis Results of Three Vehicles

\begin{tabular}{ccccc}
\hline & \multicolumn{4}{c}{ Measurement for 15 minutes } \\
\cline { 2 - 5 } & Sample & $\begin{array}{c}\text { Concentration of } \mathrm{SO}_{2} \\
(\mathrm{ppm})\end{array}$ & $\begin{array}{c}\text { Temperature } \\
\left({ }^{0} \mathrm{C}\right)\end{array}$ & $\begin{array}{c}\text { Relative Humidity } \\
(\%)\end{array}$ \\
\hline 1 & $\mathrm{X} 1$ & 75 & Increase of 6 & Increase of 26 \\
\hline 2 & $\mathrm{X} 2$ & 81 & Increase of 6 & Increase of 28 \\
\hline 3 & $\mathrm{X} 3$ & 85 & Increase of 7 & Increase of 28 \\
\hline
\end{tabular}

Table 1 shows that the lower values can be found in new, clean diesel engines, while the higher values are characteristic for older equipment and the value is still included in the diesel engine exhaust gas range, which is around 4-150 ppm [14]. The increase in temperature and humidity, among the three samples was not as significant as a differentiator. The changes in temperature and humidity of the three samples are relatively similar.

The weakness of this system is the sensitivity of the sensor which cannot know the initial conditions precisely, especially the concentration of SO2 in the container. That is caused by the sensor specifications that are not suitable for existing conditions, where the measurement range is too wide at $0-200 \mathrm{ppm}$ and the high sensor resolution is around $1 \mathrm{ppm}$, so the sensor cannot detect changes in concentration of less than $1 \mathrm{ppm}$. Therefore, the sensor must be replaced with a sensor that has the required specifications. The sensor must have a measurement range of $0-10 \mathrm{ppm}$ with a high resolution of around $0.10 \mathrm{ppm}$.

\section{Conclusion}

An integrated air quality monitoring system that combines measurements of sulfur dioxide gas, temperature, humidity, and wind speed has been successfully created and tested. The system can inform air quality both $\mathrm{SO} 2$ concentration, temperature and humidity and wind speed, online and in real-time by using the internet network.

Based on experiments, it can be concluded that the detector can read the condition of air at the time and send it to the server until it displays on the web. The system can detect changes in exhaust gas concentration with a resolution of $1 \mathrm{ppm}$, and it is also can distinguish SO2 concentrations for vehicles with different years of production.

\section{References}

[1] R. Williams, V. Kilaru, E. Snyder, A. Kaufman, T. Dye, A. Rutter, A. Russel, and H. Hafner, "Air Sensor Guidebook, US Environmental Protection Agency, Washington, DC." EPA/600/R14/159 (NTIS PB2015-100610), 2014.

[2] P. Gawande and J. Kaware, "Health and Environmental Effects of Sulphur Oxides-A Review," Int. J. Sci. Res., vol. 6, 2017.

[3] H. Yin, M. Pizzol, and L. Xu, "External costs of PM2. 5 pollution in Beijing, China: Uncertainty analysis of multiple health impacts and costs," Environ. Pollut., vol. 226, pp. 356$369,2017$.

[4] W. H. O. Joint and W. H. Organization, "Health risks of particulate matter from long-range 
transboundary air pollution," Copenhagen: WHO Regional Office for Europe, 2006.

[5] E. Apriawati and A. A. Kiswandono, "Kajian Indeks Standar Polusi Udara (ISPU) Nitrogen Dioksida (NO2) Di Tiga Lokasi Kota Bandar Lampung," Anal. Anal. Environ. Chem., vol. 2, no. $1,2017$.

[6] A. Junaidi, "Internet of things, sejarah, teknologi dan penerapannya," J. Ilm. Teknol. Infomasi Terap., vol. 1, no. 3, 2015.

[7] S. Al Farizi, E. S. Pramukantoro, and H. Nurwarsito, "Pengembangan Sistem Deteksi Karbon Monoksida Berbasis IoT,” J. Pengemb. Teknol. Inf. dan Ilmu Komput. e-ISSN, vol. 2548, p. 964X, 2018.

[8] J. M. S. Waworundeng and O. Lengkong, "Sistem Monitoring dan Notifikasi Kualitas Udara dalam Ruangan dengan Platform IoT," Cogito Smart J., vol. 4, no. 1, pp. 94-103, 2018.

[9] E. P. Wonohardjo and G. P. Kusuma, "Air Pollution Mapping using Mobile Sensor Based on Internet of Things," Procedia Comput. Sci., vol. 157, pp. 638-645, 2019.

[10] D. A. Jadhav, S. A. Patane, S. S. Nandarge, V. V Shimage, and A. A. Vanjari, "Air pollution monitoring system using Zigbee and GPS module," Int. J. Emerg. Technol. Adv. Eng., vol. 3, no. 9, pp. 533-536, 2013.

[11] G. Shi, Y. He, Y. Zhang, B. Yin, and F. Ali, "Detection and determination of harmful gases in confined spaces for the Internet of Things based on cataluminescence sensor," Sensors Actuators B Chem., vol. 296, p. 126686, 2019.

[12] I. Suryaningsih,S.; Mindara, J.Y.; Hidayat, S.; Chaerunnisa, "Design And Development Of Rf Gas Based Measuring Instruments Based On Rf Wireless For Air Pollution Condition Monitoring," J. Ilmu dan Inov. Fis., vol. 1, no. 1, pp. 45-50, 2017.

[13] S. Suryono, B. Surarso, R. Saputra, and A. Bardadi, "A web-based wireless sensor system to measure carbon monoxide concentration," in 2017 4th International Conference on Electrical Engineering, Computer Science and Informatics (EECSI), 2017, pp. 1-5. 